\title{
Improving Vocabulary Mastery Through Flashcards in Sartika Kindergarten Surabaya
}

\author{
Tiyas Saputri \\ S1 English Education Department, Faculty of Teacher Training and Education \\ Nahdlatul Ulama University of Surabaya \\ Surabaya, Indonesia \\ tiyasseunusa.ac.id
}

\begin{abstract}
This research is a study about improving vocabulary mastery through using flashcards. This research attempts to find out whether flashcards can improve the students' interest to study English, and to find out whether flashcards can improve the vocabulary mastery. The subjects of this research were the students of Sartika Kindergarten Surabaya. The researcher used a classroom action research as a method in this research. The researcher also used pretest and posttest in the teaching learning process. Based on the findings of the research, the researcher found the result of paired t-test calculation with $n=13$ and $5 \%$ incycle 1 was 0,000 , cycle 2 was 0,001 and cycle 3 was 0,000 . From the data above, Ho was rejected because significance level was $<0.05$ The researcher concludes that there is significant different between pretest and posttest mean. Therefore, using flashcards in the English Language Teaching can improve students' vocabulary mastery.
\end{abstract}

Keywords: Flashcards, Vocabulary Mastery, Classroom Action Research

\section{A. INTRODUCTION}

English is the first international language that has an important role to the beneficial development of the country. The government of each country has apparently understood the essential of learning English. Therefore, English is as one of the subject matters in the schools in most of the countries, including in Indonesia. One of the English learning aspects is vocabulary.

Vocabulary is one of the language aspects that is very important for English communication. If we have less vocabulary, we will not understand what people say. Vocabulary is needed to improve the four language skills that consist of listening, speaking, reading and writing.
Vocabulary is the most important language aspect. In fact, most of the students in kindergartenget much difficulty to learn English, especially to the vocabulary mastery. As a proof, the researchers have performed pre-research in kindergarten and the result shows that the English achievement of students is low. It can be known from the result that from 23 students only students from class A (TK A) and 7 students from class B (TK B) remember "the wild animals"vocabulary. It happened because the students did not know the meaning of question when they were tested and they did not remember the vocabulary and the pronunciation of those words. It is clear that they have lots of problems in vocabulary mastery. It may be caused by many reasons. First, the students do not have any interests in the teaching learning process. Interest is on awareness of someone that an object or case (matter) or situation always deals with him reference [1]. Interest will appear when the students aware toward education or information for their need. At school, the teachers often find that the students are not interested in learning a subject matter. It also happens in learning English, because the students do not have knowledge about the correlation between the subject matter and themselves. It becomes the teacher's responsibility to give motivation by arranging the situation, so the students are aware that there is correlation between the subject matter with their life. For example, the teachers give support and explanation to the students that learning English is very important to their life in this globalization era. The teachers also give explanation toward their students about beneficial of leaning English to their life later. Secondly, the teachers are still having less creativity when teaching English. Usually the teachers just explain the material without any games, so it can make the students bored. As teachers, they must build the interest of students to learn English by using varieties of methods. For 
example, the teachers use game in teaching learning process because the students like to play.

Finally, the use of media and method is not appropriate with the students' situation. Media and method are important in English learning process. Media and method help to understand the teacher's explanation easily. Usually the teachers use methods or media which are not appropriate with students' need. In using method or media a teacher must be adjust with the students like. The use of media and method which is not appropriate with situation or condition of the students can influence the interest and understand of them. From the situation above, we know that the students just acquire few vocabularies. This situation is also found in some kindergartens in Surabaya. One of the kindergartens is Sartika Kindergarten. In the process of teaching and learning English in that kindergarten, the teacher does not use media or method that is able to increase the interest and achievement of the students. Therefore, the researchers need to implement a media as a method of English teaching that can improve the students' interests in learning English. Based on the problems above, the researchers try to implement flashcards in teaching English in Sartika Kindergarten in order to improve the students' interests in learning English. The researchers offer flashcards media as a problem solving in learning English in Sartika Kindergarten.

Flashcards are the cards on which words and pictures or drawn. Flashcards are one of the media that can improve vocabulary mastery. Usually, the students are able to remember of English words easily if many teachers show cards that consist of words or pictures. By using flashcards, the teachers are able to teach English by employing many methods too, such as cards game, puzzle, role play, etc. Therefore, the students can be more interested and enjoy the English learning process. By employing this media, the researchers hope that these flashcards can improve the Sartika Kindergarten student's vocabulary mastery. In this research, the researchers will conduct a classroom action research, because the writer wants to know how far flashcards can improve the students' interest to learn English and vocabulary mastery.

\section{B. RESEARCH METHOD}

The research method used in this study is action research. There are some definitions of action research. The first definition is given by Kemmis in reference [4] that action research is a form of self-reflective enquiry undertaken by participants in social situation in order to improve the rationality and justices, their understanding of these practices and the situations in which the practices are carried out. Second, according to Dove Ebbutt in reference [4], action research is about the systematic study of attempts to improve educational practice by groups of participants by means of their own practical action and by means of their own reflection upon the effects of those actions. Third, definition is given by Robert Rapport in reference [4] that action research aims to contribute both of the practical concerns of people in an immediate problematic situation and to the goals of social science by joint collaboration within a mutually acceptable ethical framework. Based on many definitions above about action research; the researcher can conclude that action research is one of form of research that trying out an idea in practice of a social situation with a view to improving or changing something, trying have a real effect on the situation.

The procedures of this research are illustrated in the following scheme. (Planning-ActionObservation- Reflection)

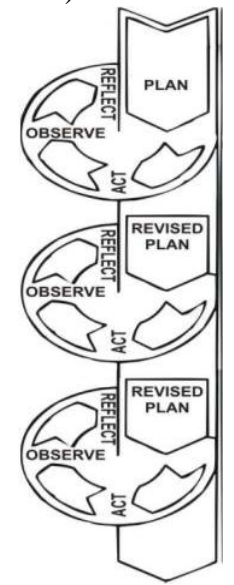

In the research, the researcher uses some steps as Kemmis stated. There are tree cycles in this action research. In each cycle the procedure are as follows:

1. Planning

2. Action

3. Observation

4. Reflection

The classroom action research will be carried out at Sartika Kindergarten Surabaya. It is located at J1. Ketintang PTT IV / 38 - Surabaya, East Java. Sartika Kindergarten has two classes, the first class is A class and the second class is B class. It consists of 13 students. There are 5 boys and 8 girls.

Table 1.The name of the subjects of the study

\begin{tabular}{|c|c|l|}
\hline No. & $\begin{array}{c}\text { Students } \\
\text { Number }\end{array}$ & \multicolumn{1}{c|}{ Students Name } \\
\hline 1 & 932 & Aisyah Putri Ramdani \\
\hline 2 & 934 & $\begin{array}{l}\text { Muhammad Rizqy } \\
\text { Mubarok }\end{array}$ \\
\hline 3 & 935 & Calista Keyla Putri \\
\hline 4 & 936 & $\begin{array}{l}\text { Cinta Pinangan } \\
\text { Rembulan }\end{array}$ \\
\hline 5 & 937 & $\begin{array}{l}\text { Danendra Dwi Putra } \\
\text { Setyoko }\end{array}$ \\
\hline
\end{tabular}




\begin{tabular}{|c|c|l|}
6 & 938 & Diva Wahyu Aprilia \\
\hline 7 & 939 & Hairar Putra Aditya \\
\hline 8 & 940 & Margareta Oktafiani Dias \\
\hline 9 & 941 & Nata Litha Puteri \\
\hline 10 & 942 & Shakila Alayya \\
\hline 11 & 943 & $\begin{array}{l}\text { Wicaksono Akbar } \\
\text { Darmawan }\end{array}$ \\
\hline 12 & 944 & $\begin{array}{l}\text { Mutiara Nuraisyah Az } \\
\text { Zahra }\end{array}$ \\
\hline 13 & 945 & Muhamad Dzaky Jamail \\
\hline
\end{tabular}

There are two ways to analyze the data, they are:

1. Descriptive technique

A descriptive technique is used to know the students' behavior during the teaching learning process. In descriptive technique the researcher will analyze the observation sheet which had been made by her partner.

2. Statistical Technique

A statistical technique is used to know is there any influence to the students' vocabulary or nofrom the result of pretest and posttest. This research was calculated by statistical test analysisof IBM SPSS Statistics 20 using compare means paired samples t-test.

\section{RESULT}

In this research implementation, the data consist of pretest, posttest andfield note. The data of pretest and posttest will show the improvement of thestudents' achievement in vocabulary. (How far is the improving students'vocabulary by using flashcards?) Field note will show the students' behavior inteaching learning process. (How far is their interest in teaching learning process?)Based on the explanation about procedure of action research above, the researcher had arranged three cycles. In each cycle, the steps are planning, acting, observing and reflecting.

By observing the teaching learning process in cycle 1 , cycle 2 andcycle 3 , she concludes that flashcards can improve the students'vocabulary. The improvement can be seen through the result of activity from cycle 1 , cycle 2 and cycle 3 .

Cycle 1 (December 09 ${ }^{\text {th }}, 2016$ ):

In the first cycle, she and her collaborator observed the teaching learning process. By monitoring the students' activity in this action, the teacher can see that the students still get difficult to say some words in English. Some students pronounced them incorrectly. Cycle 2 (January 06 ${ }^{\text {th }}, 2016$ ):

In the second cycle, observation was also carried out during implementation of the action. The researcher got field note from the partner which has been written above. By monitoring the student's activity in the action, the teacher can see that the students still get difficulty to say some words in English. Some students' pronunciation was still incorrect and this can be known from the posttest result.

Cycle 3 (January 12 ${ }^{\text {th }}, 2016$ ):

The teacher observed in the third action, while she was monitoring, she helped the students when they got difficulties. She was trying hard to activate the students who were still quiet in repeating the words said the teacher by giving guidance.The teaching learning process in action 3 was increasing the studentswho said words incorrectly; they can say correctly, there were a few students who found difficulties to pronounce the words about wild animals in English. The teachinglearning process was very active.

After analyzing the result of cycle 1 , cycle 2 and cycle 3 , it can be concluded that using flashcards can increase the interest of students to involve actively in learning vocabulary in the class. The result of pretest and posttest of oral test were used to know the score of vocabulary mastery. As stated before there were three cycles in this action research, each cycle used pretest and posttest of oral test. Pretest and posttest consist of 10 test item. She gave pretest to students before teaching and gave posttest after she taught ineach cycle. She gave a question that must be answered by the students orally. The pretest and posttest of oral test was used to know the students who can answer correctly.

\section{DISCUSSION}

From the result of analyze in cycle 1 , cycle 2 and cycle 3, the researcherwill analyze the students' improvement from cycle 1 to cycle 3 . The improvement as follows:

Table2.The analysis of students' improvement Paired Samples Statistics

\begin{tabular}{|lc|r|c|c|c|}
\hline & & Mean & $\mathrm{N}$ & $\begin{array}{c}\text { Std. } \\
\text { Deviati } \\
\text { on }\end{array}$ & $\begin{array}{c}\text { Std. Error } \\
\text { Mean }\end{array}$ \\
\hline Pair 1 & pretest & $\begin{array}{r}7.069 \\
2\end{array}$ & 1 & .43086 & .11950 \\
& posttest & 7.392 & 1 & & \\
& pretest & 7.392 & 3 & .45178 & .12530 \\
& 2 & 3 & 3 & .45178 & .12530 \\
Pair 2 & posttest & 7.800 & 1 & .59442 & .16486 \\
& 2 & 0 & 3 & & \\
& pretest & 7.800 & 1 & .59442 & .16486 \\
& 3 & 0 & 3 & & \\
Pair 3 & posttest & 8.353 & 1 & .60362 & .16741 \\
& 3 & 8 & 3 & \\
\hline
\end{tabular}


Paired Samples Correlations

\begin{tabular}{|ll|r|r|r|}
\hline & N & $\begin{array}{r}\text { Correlati } \\
\text { on }\end{array}$ & Sig. \\
\hline Pair 1 & $\begin{array}{l}\text { pretest \& } \\
\text { posttest } \\
\text { pretest2 \& } \\
\text { posttest2 } \\
\text { pretest3 \& } \\
\text { posttest3 }\end{array}$ & 13 & .915 & .000 \\
Pair 2 & 13 & .816 & .001 \\
Pair 3 & .836 & .000 \\
\hline
\end{tabular}

Paired Samples Test

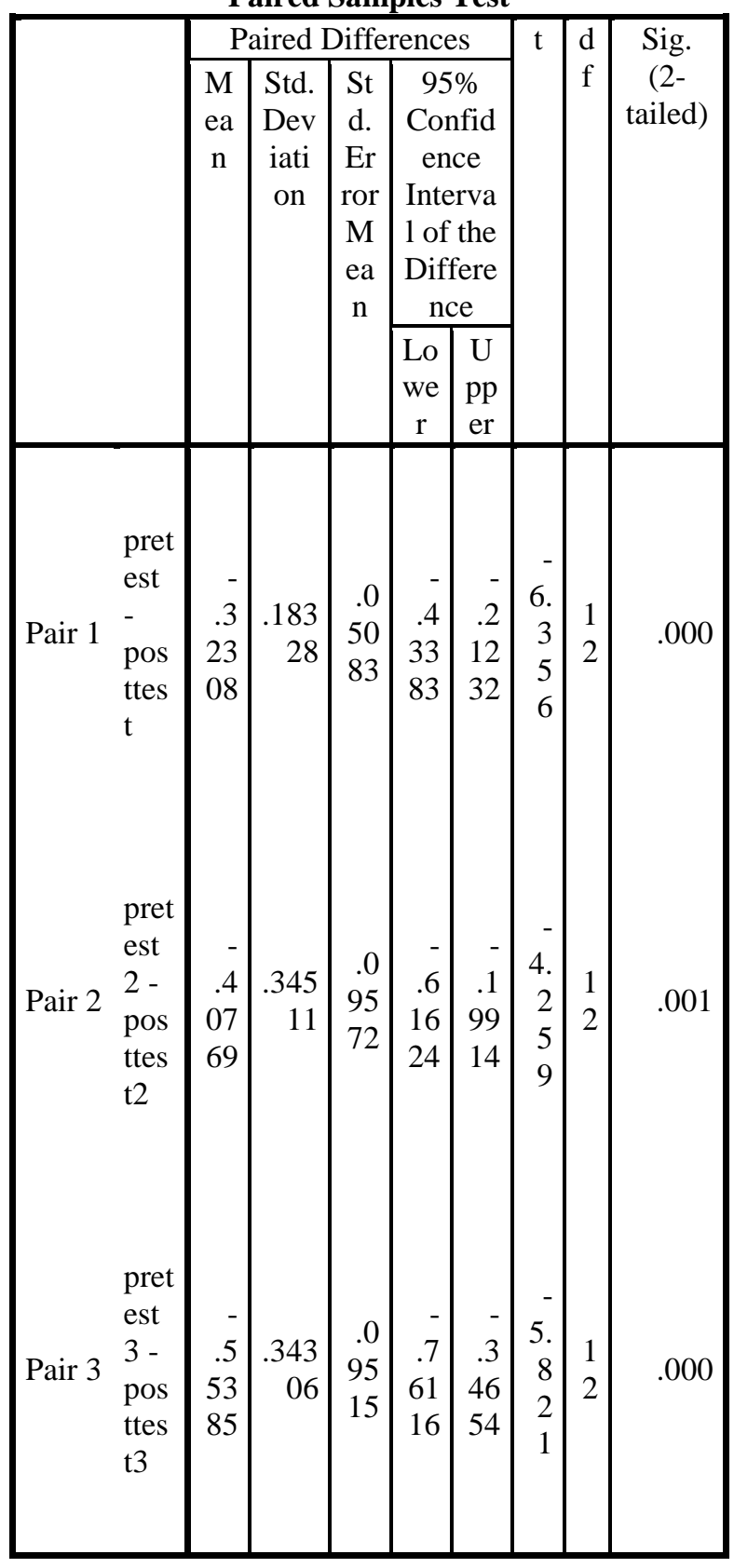

If significance $<0,05$ (Ho is rejected), if significance $>0,05$ (Ho is accepted). If significance $<0,05$ (Ho is rejected), meansthere is significance different between pretest and posttest mean. From the data above, Ho is rejected because significance level is $<0.05$ therefore there is a significant different between pretest and posttest mean. It shows that flashcards give influence in improving students' vocabulary because the student's achievement has been increase after the students did the flashcards. It means that flashcard is appropriate with the situation and condition of students in Sartika Ketintang kindergarten in learning English especially in vocabulary. Besides, the students are more interested and involved actively in teaching learning process. From the finding research above, it is shown that flashcards can improve the students' vocabulary mastery. So, this research proves that flashcard is useful in the teaching learning processespecially in teaching vocabulary.

\section{E. CONCLUSION RECOMMENDATION}

AND

\section{Conclusion}

Based on the explanation above, the researcher concludes that the use of flashcards in teaching English, especially in teaching vocabulary to the students of Sartika Kindergarten is able to improve students vocabularymastery. For the result of the research shows that flashcards of teaching vocabulary is able to help the students to improve their vocabulary mastery from the paired t-test calculation. The result of paired t-test calculation with $\mathrm{n}=13$ and $5 \%$ in cycle 1 was 0,000 , cycle 2 was 0,001 and cycle 3 was 0,000 . If significance $<0,05$ ( $\mathrm{Ho}$ is rejected), if significance $>0,05$ ( $\mathrm{Ho}$ is accepted). From the data above, Ho was rejected because significance level was $<0.05$, therefore there was a significant different between pretest and posttest mean. It showed that flashcards gave influence in improving students' vocabulary because the student's achievement had been increased after the students did the flashcards. It means that flashcard is appropriate with the situation and condition of students in Sartika Ketintang kindergarten in learning English especially in vocabulary. Besides, the students were more interested and involved actively in teaching learning process.

\section{Recommendation}

Based on the result and conclusion, the researcher wouldlike to suggest as follows:

1. To the teachers

They should enhance their ability in teaching English especially when she taught by using flashcards to improve vocabulary mastery, so thestudents will remember the words easily. They 
should teachvocabulary effectively. So, teachers' role in teaching learning process can influence students in improving their vocabulary mastery. Besides, theyshould ask the students to study English continually.

2. To the students

Student should always be active in teaching learning process and not be afraid of English lesson. They should study English continually in classroom and in their home. When the teacher is teaching vocabulary, they should pay attention to the teacher's explanation.

3. To the researcher

It is hoped that the result of the study makes the English teacher use an appropriate teaching mode of presentation on improving student's vocabulary mastery. Hopefully, the result of the study can be used as additional reference for further research with the different sample and occasions.

\section{F. REFERENCES}

[1] Djamil, Noerhadi. 1997. IlmuJiwaPendidikan. Semarang: FakultasTarbiyah IAIN Walisongo Semarang.

[2] Edwards, Stephen. 2006. 50 Ways to to Improve Your study Habits. Kuala Lumpur: Golden Book Center.

[3] Harmer, Jeremy. 2002. The Practice of English Language Teaching. England: Longman.

[4] Hopkins, David. 1993. A Teacher's Guide to Classroom Research, Philadelphia, OpenUniversity Press.

[5] Hornby, 1974. Oxford Advanced Learner's Dictionary of Current English. New York: Oxford University

Press.http://testprep.about.com/od/tipsfortesting/ht/M ake_Flashcards.htm taken on 30 December 2016

[6] Komachali\&Khodareza. 2012. The Effect of Using Vocabulary Flash Card on Iranian Pre- University Students Vocabulary Knowledge. International Education Studies. ISSN1913-9020. http://dx.doi.org/10.5539/ies.v5n3p134.

[7] NadzirohAschurotun. 2010. The Use Of Flashcards To Improve Vocabulary Mastery (A Classroom Action Research For The Fourth Year Students Of Mi Duren BandunganIn The Academic Year Of 2009 /2010).

[8] Richard, Jack C. 2001. Curriculum Development in Language Teaching. United States of America: Cambridge University Press.

[9] Sudarmanto. 1993. TuntunanMetodologiBelajar. Cetakan ke-2. Jakarta: PT. Grasindo.

[10] Suyanto\&Kasihani K. E. 2008. English for Young Learners. Jakarta: BumiAksara.

[11] Thornbury, Scott. 1990. How to Teach Vocabulary. England: Longman.

[12] Webster, Merriam. 1961. Webster's Third New International Dictionary and Seven Language Dictionary. USA. 